\title{
Modeling features of sustainable urban development in modern conditions of water supply
}

\author{
Alina Furtatova ${ }^{1 *}$ and Lyudmila Kamenik ${ }^{1}$ \\ ${ }^{1}$ Peter the Great St.Petersburg Polytechnic University, Polytechnicheskaya, 29, St. Petersburg, \\ 195251, Russia
}

\begin{abstract}
The purpose of this research is to show that the water supply of territories is the basic factor for the growth of modern cities. Analytical methods of scientific research were used in this study. Analysis of modern water supply was carried out to identify the problems in this area. Nowadays, there have been negative trends in water supply, affecting the growth of cities, which were indicated by the authors as the modern conditions for the sustainable urban development. The problems of modern water supply are: limited access of the population to guarantee sources of water supply, an increased level of environmental pollution, and an inadequate financing in the field of water supply, whose purpose is to provide qualitative water supply services for the consumers. These specific features in a field of water supply complicate the implementation of sustainable urban development concept. Providing sustainable development is impossible without integrated consideration of socioecological-economic and natural factors. The result of the study consists in the necessity of taking into account the potential of city development in terms of water availability per person during the modeling sustainable urban development.
\end{abstract}

\section{Introduction}

Water supply of modern cities plays an important role for the life support of the population. The quality of life and development of society depend on the quality of portable water supply services. To date, there are increases in urban population, anthropogenic pressure on the environment, degradation of natural ecosystems and, as a result, an increase in the scarcity of portable water [1]. Study showed that in relation to negative aspects of modern modeling of sustainable urban development, it is necessary to take into account the potential of territory water supply and its impact on the growth of the cities and the boundaries of their expansion.

The purpose of the study is the importance to take into account the potential of the city's development in terms of water availability per person when modeling sustainable urban development.

\footnotetext{
${ }^{*}$ Corresponding author: alina_furtado@mail.ru
} 
Sustainable urban development should not only mean three aspects - ecological, economic and social, but also the natural factor. In the reports of the United Nations, they pay special attention to the world's water supply - as a main natural factor, which contributes to sustainable development $[1,2]$.

\section{Reviews of modern condition of water supply}

Water is one of the most crucial natural resource involved in the economy. Because of the volume of annual water usage, it far exceeds the mass of all the main extracted resources [3]. It is an essential resource for the production of all goods, services and for the development of energy and industry. However, nowadays, the importance of water supply services is underestimated, which often leads to unstable usage of water resources and environmental degradation [4].

The distribution of water services for population is the most important factor, which contributes to sustainable development and improves the standards of living. Therefore, it is important to ensure uninterrupted access to water services by maintenance of this industry at the highest level of quality. It is necessary to provide timely repair of equipment, technical refurbishment of production, reconstruction and modernization of wastewater treatment plants. It requires the introduction of modern technologies to ensure rational usage of water resources and optimize management system in the field of water supply [5].

This industry requires large financial support for the ensuring continuity of water supply [1]. It will assist to achieve an optimal distribution of water resources, reduce environmental pollution, and improve the quality of provided services. Thereby it leads to increase the consumer's satisfaction with portable-water quality.

"The Global trends: paradox of progress" report, published by the National Intelligence Council in early 2017, contains information about the future development of society in terms of modern conditions, which are formed by the impact of global problems such as freshwater scarcity, climate change or pollution [6]. The forecasts until 2035 is not optimistic. The problem of global freshwater scarcity in the future will become more urgent and will affect negatively sustainable urban development. These problems will concern all regions despite of their currently amount of water resources.

"Ensure access to water and sanitation for all" is one of the important aims of sustainable development, which was allocated in the report "Sustainable Development Goals 2017", published by the United Nations. This part of the report emphasizes the importance to invest in the water and sanitation sector for the improvement of usage of water resource efficiency and assurance safe access to water sources for population [1].

"Water for a sustainable World" report, published by the United Nation in 2015 is based on consideration of water resources in regions of the world in the context of three main aspects of sustainable development - social, environmental and economic [2]. The present condition of the regions is presented in terms of their sources of water supply. The purpose of the report is to illustrate the importance and the priority of rational use of water resources due to these resources are the basis for sustainable urban development.

The seventh chapter of the 2017 Report on Human Development in the Russian Federation "Environmental priorities for Russia", prepared by the Analytical Center to the Government of the Russian Federation, is devoted to issues about water resources conditions in Russia and in the World. The following issues are - forecasts of global water consumption and world water availability per person; main environmental problems of water supply; ecological conditions of Russian water sources and ways of optimization of the water management complex in Russia [3].

The methodological basis of the research is the application of analytical methods, including analysis, synthesis and comparative methods of scientific research. The analysis 
of the current state of water supply in Russia and in the Word, forecasts of population growth and environmental degradation too (based on the above reports) was primarily carried out. The conclusion of the research was taken during the comparison of conditions in the field of water supply in different countries of the World and consisted in the importance of focusing on global issue of freshwater scarcity. The analysis of current state of the world's water supply resulted in the posing of the problem of the necessity of modeling the sustainable urban development based on the possibilities of water supply of the territories.

Water resources are the basis for sustainable urban development. The availability of water resources and water services contributes to the reduction of poverty, economic growth and environmental sustainability that could eventually improve social well-being in general [2].

Actually, there is a growing number of countries, which suffer from water scarcity due to the population growth, urbanization, economic development, climate change, and water mismanagement [7]. All these aspects lead to increasing tension between countries about the access to water resources.

Many countries around the World have lack of security in the provision of water resources. For instance, Cambodia, Laos and Thailand are constantly suffering because of droughts, which emphasizes freshwater scarcity problem in these regions. In parts of SouthWest Asia, more than $80 \%$ of the population does not have secure access to portable water [6]. Consequently, more and more countries in the nearest future will be affected by lack of qualitative portable water. As a result, organization of water supply infrastructure and introduction of technologies for rational water use are the crucial points to achieve sustainable development goals.

Water resources provide three essential functions for humanity - food, energy and industrial production, household water supply, sanitation and hygiene [3]. Agriculture utilizes for almost $70 \%$ of the world's water consumption (this indicator sometimes reaches $95 \%$ in developing countries). In other words, this situation represents a major challenge for sustainable development, due to significant increasing in agricultural production to enable global food needs. Therefore, the protection and more efficient usage of water resources will have the importance, both in food production and in other sectors [4].

By the middle of the 21 st century, $40 \%$ of the world's population will experience water scarcity, and $20 \%$ will suffer seriously, according to the World Bank estimations [3]. That means on the one hand, the future global water consumption will increase due to the necessity of an economic growth, but on the other hand the amount of available freshwater resources will continue decreasing quickly.

Increasing the usage of water resources, primarily leads to their pollution, as the water, which was used by consumers, contaminate water basins. The result is the shortage of natural and secure freshwater. If the process of environmental degradation does not stop, freshwater scarcity will increase [8]. Thus, reducing the anthropogenic impact on the environment and implementation "green" production and consumption will be necessary condition to solve the global issue of freshwater scarcity.

The problems, which connect with water supply and sustainable urban development, vary on the regional features of the territory.

Increasing resources efficiency, reducing wastes and level of pollution that affects water usage and selecting appropriate water treatment technologies are major challenges for European and North American countries [2].

Ensuring sustainable water resource development in the Asian and Pacific regions is related to providing with secure access to portable water for the population by introducing technologies for water resources recycling and improving water management in general [2]. 
The problem of scarcity of freshwater is also relevant for the Arab region. The limited access to secure water sources for the population hinders the achievement of sustainable development in the region. Specific feature of these territories is large amount of drylands, which negatively influence on water resources distribution and lead to freshwater scarcity that threaten long-term sustainable development of the region [2].

The main priority for Latin America is the modernization of water resource management to maintain the socio-economic development of the region, due to their high level of water resources [2].

The fundamental aim for the countries of the African region is to achieve durable participation in the global economy, while developing their natural and human resources. Only 5\% of the Africa's potential water resources are developed to date, however the continent has a great water potential [2].

\section{General characteristics of water potential}

The review about the issues of sustainable urban development in terms of water supply should start with general understanding of the characteristics of the water potential.

The table below shows the gross amount of water resources and water availability of the six leading countries of the world [3].

Table 1. Gross amount of water resources and water availability of the six leading countries of the world.

\begin{tabular}{|c|c|c|}
\hline Country & River flows resources, $\mathrm{km}^{3} / \mathrm{year}$ & $\begin{array}{c}\text { Water availability, thousand } \mathrm{m}^{3} / \\
\text { year per person }\end{array}$ \\
\hline Brazil & 8120 & 42.2 \\
\hline Russia & 4348 & 28.7 \\
\hline Canada & 3420 & 109 \\
\hline USA & 3048 & 10,6 \\
\hline China & 2700 & 2.1 \\
\hline India & 2037 & 1.7 \\
\hline
\end{tabular}

The analysis was carried out and it showed the problem of inadequate water supply per person in China and India. Their river flows resources are 2700 and 2037 cubic kilometers per year, respectively. These amounts of water resources are considered to be leading in relation to the water supply of European countries. However, water availability per person assumes the lowest values -2.1 and 1.7 thousand cubic meters, respectively due to the fast growth of the population in China and India.

This statistic example shows that freshwater scarcity has become one of the most essential problems of the century. Future wars will be in order to the lack of fresh water resources, according to futurist's estimations [6]. Therefore, nowadays it is so crucial to implement projects of modeling of sustainable urban development, depending on the level of water availability in the region.

Gross amount of freshwater in the Russian Federation is the second highest in the World. It possesses the third largest water availability per person.

The river flows resources in large regions of the World have been distributed as follows (in thousand cubic meters per year): Asia accounts for 3.1, South America - 32, North America - 15, Africa - 5.7, Australia and Oceania - 83 and Europe - 4.1. The World average level of river flows resources is 8 thousand cubic meters per year. This indicator exceeds the regional rates of the European, Asian and African countries, which emphasizes the priority consideration of the issue of global water scarcity [3]. 


\section{Ways to solve the problems of water supply in the Russian Federation}

In the Russian Federation, even its second place in the World after Brazil in terms of the amount of water resources, there is still a scarcity of freshwater in many regions due to its uneven distribution and high levels of contamination of water basins.

The developed areas of the European part of the country, where more than $70 \%$ of the population and production capacity are concentrated, represent no more than $10 \%$ of water resources. In low-water years, water scarcity appears in areas of intensive economic activity in the basins of the rivers Don, Ural, Kuban, Irtysh, and on the western coast of the Caspian Sea [3].

The condition of the Volga River is an example of the difficult environmental situation. That is because practically all water basins suffer from anthropogenic impact and the quality of water in them does not meet regulatory requirements [3].

About 109 million people use the services of public water supply in the Russian Federation, but it is just near $75 \%$ of the country's total population. According to the level of public water supply systems access for the population, the Russian Federation is inferior to developed countries, where this indicator is $90-95 \%$ [3].

The level of consumer's dissatisfaction with the quality of portable water in the Russian Federation is growing every year, because of the high level of contamination of water sources and the usage of inefficient water treatment technologies [5]. Therefore, today it is necessary to develop a system of measures connected with the recovering quality of water in water basins that have experienced excess anthropogenic pressure. This system of measures involves the introduction of innovative water treatment technologies to urban waterworks, such as closed resource cycle technology, which ensures the rational use of available water resources [9]. This activity should be financed from public funds, organizations and business. Ensuring the interest of business in such participation is a major and responsible economic goal. It is crucial to provide financial interest, both for business and government in the same way, through the implementation of mechanisms of publicprivate partnership.

In 2009, in order to solve the existing problems in Russia on the field of water supply, "Water Strategy of the Russian Federation up to the year 2020" was developed. The main aim was to provide sustainable water supply in Russia [10]. The underlying principles of the Strategy are the comprehensive modernization of the country's water supply system to rationalize the usage of water resources (the introduction of innovative resource-saving technologies) and the improvement of the organization of water supply management (the formation of a common information and analytical water supply management system). For these reasons, the needs of the population and sectors of the Russian economy in water resources will be based on the comprehensive (integrated) approach to water resource management.

The fundamental directions of increasing the water usage rationality for industrial enterprises are economic incentives to reduce specific water consumes, unproductive water losses and introduction of water-saving technologies [10]. Implementation of water recycling and re-use systems is an option, for instance the technologies of a closed resource cycle that aim at maximizing the usage of all available resources in the production process [11].

To optimize the process of financing for enterprises (at their own expense), it is necessary to introduce concessional lending for the implementation of measures for the construction, reconstruction and modernization of water recycling and reuse systems and the introduction of innovative technologies [10]. In addition, prospective solution in the field of financing these projects will be the implementation of public-private partnership 
mechanisms based on long-term government and business engagement for the development of public infrastructure.

The analysis of water availability in Russia and other countries of the World showed how acute is the problem of water scarcity today.

Today, more than 2 billion people face against the scarcity of fresh water, and their number will only increase due to the effects of climate change and population growth, according to the United Nation forecasts [1]. Providing global access to portable water in addition to safety requirements has been a difficult problem for nowadays.

The current situation with the freshwater scarcity contributes to the risk on the growth of limited access for the urban population to secure and quality portable water, due to the increasing amount of environmental pollution. The underground and surface water sources are particularly affected by heavy contamination. Therefore, future water treatment requires deeper cleaning water technologies, which the help of impurities, remove useful substances from water [11]. The introduction of these technologies will not promote the rational use of water resources, but will require new costs for the development of technology and the acquisition of appropriate equipment.

It is important to pay attention to the fact that there will be an increase in the costs of water treatment due to raising costs of maintenance of technological processes and the equipment in the cost of product. It is also possible to increase the load on existing equipment, which will also contribute to the increase in production costs because of the cost of repairs and in addition increase the risk of emergencies at production facilities [5]. Consequently, these measures will extend the cost of the water treatment process, which will directly affect the growth of consumer's payment for water supply services. Payments for services of water supply will grow, but the quality of water supply services will not improve due to widespread pollution of water resources and limited access for the consumers to secure water sources.

Therefore, during the long-term planning and modeling of the sustainable urban development, it is necessary to take into account the potential of city development in terms of water availability per person. Implementation of this innovative model of sustainable urban development requires an integrated approach to enable rational usage of water resources. On the one hand, it concerns enterprises that they need to introduce resourcesaving technologies. On the other hand - consumers who need to realize the importance of careful and efficient usage of water resources.

\section{Results}

According to the authors, in the future, it will be necessary to planning and modeling the development of cities and taking into account the water availability of their territories. It is required to provide the most efficient use of available water resources and promote the resource-saving production to ensure sustainable urban development [12]. It is necessary to use innovative technologies in production that contribute to maintaining water potential of the regions. One of these technologies is the technology of a closed resource cycle, whose purpose is to provide an optimal use of water resources during purification and their further recycling process [5].

The field of water supply includes two basic elements: the water supply system and the sewage system. Reagent water treatment technologies are applied in water supply systems, mechanical and biological purification technologies are applied in the sewage systems [13]. These technologies seem to be effective from the point of view of qualitative purification of portable water, and for the treatment of wastewater. However, the issue of recycling of the treated and disinfected water is still unresolved. 
For instance, nowadays, $98.5 \%$ of wastewater in St. Petersburg is cleaned up by treatment facilities. The technology of deep removal of nutrients (nitrogen and phosphorus) has been introduced at sewage treatment plants [13]. The next step is the disposal of these substances by burning. However, at present all disinfected water is discharged into a large water basin. Then, it is necessary to introduce the concept of closed resource cycle technology in the field of water supply of St. Petersburg [11]. The priority of this concept is to ensure the introduction of this technology for the deep processing of water resources for their further use [9]. This concept is innovative, because it represents the urgency of the modern water supply conditions, in case of the current scarcity of water resources [14]. Therefore, planning and modeling of sustainable urban development should take into account the factor of regional water availability.

Urban development planning taking into account the factor of water availability of the territory is urgency and priority goal in terms of existing condition in the field of water supply on the example of St. Petersburg. Thus, it is required of complex modernization of water supply system, taking into account the usage of innovative closed resource cycle technology, in order to ensure deep processing and rational use of water resources [5]. Private investors should support financing of these activities through the mechanisms of public-private partnership. It also requires the systematization of information and materials about water supply conditions of large cities, territory water availability per person and modern resource-saving water technologies, which cannot be achieved without the development and implementation of large databases $[15,16]$.

\section{Conclusions}

The results obtained during the study show the following conclusions about the necessity to take into account the potential of water supply for the modeling of sustainable urban development. The results are:

1. For now, the problem of limited access of the population to secure sources of water supply is aggravated due to the rapid population growth and degradation of the environment. As a result, water supply potential of urban areas is decreasing.

2. During the modeling of sustainable urban development, it is necessary to take into account the potential of cities possible growth by the factor of water supply per person, which in modern conditions of water supply seems to be priority and urgent factor.

3. The solve about of the problem of the necessity of modeling the sustainable urban development due to the potential of water availability of the territory is the implementation of innovative model of water supply. The major challenge of this model is the introduction of resource-saving technologies, as the closed-resource cycle technology, which focuses on providing deeper processing of water resources.

\section{References}

1. The Sustainable Development Goals Report (United Nations, New York, 2017)

2. The United Nations World Water Development Report. Water for a sustainable World (United Nations Educational, Scientific and Cultural Organization, 2015)

3. S.N. Bobyleva, L.M. Grigor'yeva, Human Development in the Russian Federation "Environmental Priorities for Russia" (Analytical Center to the Government of the Russian Federation, 2017)

4. L. Rattan, Agronomy journal 107(4), 1526-1532 (2015) 
5. A.S. Furtatova, L.L. Kamenik, Competitiveness in a global world: economics, science, technology 8-1(55), 129-131 (2017)

6. Global Trends Paradox of Progress, National Intelligence Council 5, 29 (2017)

7. G. Madin, E. Charlotte, Water International 41(5), 801-803 (2016)

8. T. Bibikova, S. Acharjee, I. Vishnevskaya, Proc. of the VIIIth Int. Sc. Conf. of the Young Scientists and Talented Students "Water Resources, Ecology and Hydrological Safety”, 22-25 (2014)

9. L.L. Kamenik, Economy and Enterepreneurship 3(56), 177-184 (2015)

10. V.I. Danilov-Danil'yan, M.V. Bolgov, O vodnoy strategii Rossiyskoy Federatsii na period do 2020 goda. Vodnye problemy krupnykh rechnykh basseynov $i$ puti ikh resheniya. Sbornik nauchnykh trudov (2009)

11. A.S. Furtatova, L.L. Kamenik, Journal of Economy and enterepreneurship 11, 868-873 (2017)

12. L.L. Kamenik, Resursosberegayushchaya politika i mekhanizm ee realizatsii v formate evolyutsionnogo razvitiya. (Sankt-Petersburg, 2012)

13. Vodosnabzhenie i vodootvedenie v Sankt-Peterburge, Novyy zhurnal, 464 (2008)

14. V.I. Danilov-Danil'yan, Vestnik Rossiyskoy Akademii Nauk 77(2), 108-114 (2007)

15. I.V. Ilin, O.Yu. Iliashenko, A.I. Levina, Application of Service-Oriented Approach to Business Process Reengineering. Proc. of the 28th Int. Business Information Management Association Conf. - Vision 2020: Innovation Management, Development Sustainability, and Competitive Economic Growth, 768-781 (2016)

16. A.V. Kozlov, E.V. Rytova, S.S. Gutman, I.M. Zaychenko, The valuing of the indicator of a regional industrial development: The fuzzy logic approach XIX IEEE International Conference on Soft Computing and Measurements (SCM), 545-547 (2016) 